\title{
Pelindungan Hukum Bagi Production House Terhadap Penyiaran Film yang Sedang Tayang di Bioskop Tanpa Izin Melalui Media Sosial
}

\author{
Alvieta Dewina \\ Fakultas Hukum Universitas Padjadjaran \\ Alvietadewina9@gmail.com \\ Rika Ratna Permata \\ Dosen Fakultas Hukum Universitas Padjadajran \\ Helitha Novianty Muchtar \\ Dosen Fakultas Hukum Universitas Padjadjaran
}

DOI: 10.23917/laj.v5i1.10399

Submission

Track:

Received:

27 February 2020

Final Revision:

16 Maret 2020

Available online:

28 April 2020

Corresponding

Author:

Alvieta Dewina

alvietadewina9@gmail.com

\begin{abstract}
ABSTRAK
Penelitian ini bertujuan untuk meninjau perlindungan hukum bagi rumah produksi sebagai pemegang Hak Cipta serta memberikan pengetahuan mengenai tindakan hukum yang dapat dilakukan oleh rumah produksi terhadap kerugian ekonomi yang ditimbulkan atas tindakan penyiaran film bioskop tanpa izin melalui media sosial. Hukum bersifat dinamis berjalan seirama dengan perkembangan masyarakat dan telah memasuki era digital. Penyiaran film bioskop tanpa izin melalui media sosial merupakan contoh perbuatan melawan hukum telah memasuki dunia digital beserta konsekuensinya. Penelitian ini diharapkan dapat menciptakan kesadaran pada masyarakat bahwa pembajakan dapat menimbulkan kerugian baik materil maupun imateril terutama bagi rumah produksi. Penelitian ini menitikberatkan pada pembajakan yang telah berkembang ke dalam jenis baru, yaitu pembajakan melalui media sosial, khususnya penyiaran kembali melalui Bigo Live. Penelitian ini menggunakan metode analisis data yuridis kualitatif. Metode yang digunakan adalah penelitian literatur yaitu penelitian secara normatif khususnya Undang-Undang Nomor 28 Tahun 2014 Tentang Hak Cipta. Penyiaran kembali film bioskop tanpa izin melalui media sosial merupakan pelanggaran Hak Cipta berdasarkan Undang-Undang Hak Cipta. Penelitian ini juga menyimpulkan bahwa rumah produksi merupakan badan hukum yang dilindungi oleh Undang-Undang Hak Cipta sebagai Pencipta, sehingga rumah produksi mendapatkan pelindungan hukum atas segala bentuk pelanggaran Hak Ekonomi dan Hak Moral Pencipta, termasuk pada dunia digital. Penelitian ini menyimpulkan bahwa pihak rumah produksi selaku pemilik Hak Cipta sebuah karya film
\end{abstract}


dapat melakukan gugatan hukum secara perdata atas kerugian ekonomi berdasarkan Pasal 95 dan 96 Undang-Undang Hak Cipta dan juga secara pidana sesuai dengan ketentuan Pasal 105 UndangUndang Hak Cipta.

Kata Kunci: Penyiaran Film, Media Sosial, Pembajakan, Rumah Produksi

\begin{abstract}
This study aims to observe the legal protection of production houses as the copyright owner and provide knowledge about legal actions that can be carried out by the Production House against the economic losses incurred by the act of broadcasting cinema films without permission through social media. Law has a dynamic nature, it goes along with the development of society and has entered the digital world. Unauthorized broadcasting of cinema films through social media is an example that illegal act has entered the digital world along with its consequences. This research is expected to be able to raise awareness in the community that acts of piracy can have an impact on both material and immaterial losses, especially for the Production House. This research focuses on piracy that has evolved into a new category, which is the acts of piracy through social media, in particular, the broadcasting of cinema film through Bigo Live. This paper used the data analysis method of qualitative juridical. The method used in this paper is literacy research, which is normative research, particularly Law No. 28 of 2014 regarding Copyright. Re-broadcasting cinema films without permission through social media is a violation of copyright under the Copyright Act. This research also concluded that the Production House is a legal entity that is protected by the Copyright Act as an Author, therefore the Production House is legally protected for all forms of violation of economic rights and moral rights of the Author, including in the digital world. This study concludes that the Production House as the Copyright holder could make a civil lawsuit for economic losses according to Articles 95 and 96 of the Copyright Act and also criminally in accordance with the provisions of Article 105 of the Copyright Act.
\end{abstract}

Keywords: Film broadcasting, Social Media, Piracy, Production House

\title{
PENDAHULUAN
}

Globalisasi merupakan proses input untuk mendunia dengan indikasi setiap negara saling bekerja sama tanpa sekat antar negara (Nasution, 2017). Faktor utama masuknya era 
globalisasi adalah kemajuan teknologi informasi, sehingga membentuk fenonema yang dikenal dengan digitalisasi masyarakat. Adagium yang menyatakan, "information is the lifeblood that sustains political, social, and business decision", mendukung realitas bahwa kemajuan teknologi informasi mampu menopang peradaban suatu negara. Perkembangan teknologi informasi bergaris lurus dengan kemajuan ilmu pengetahuan dan inovasi hasil ciptaan manusia untuk mempermudah aktivitas sehari-hari dengan dukungan internet.

Perkembangan internet berdampak pada terbentuknya jaringan yang lazim dikenal dengan istilah media sosial. Media sosial tidak hanya berfungsi sebagai sarana untuk mempermudah komunikasi, melainkan sarana untuk mempublikasikan keseharian individu, mengembangkan kreativitas, meningkatkan popularitas, serta mempromosikan komoditi dan komoditas.

Perkembangan internet telah memberikan banyak dampak positif bagi masyarakat, namun suatu inovasi tidak dapat terlepas dari dampak negatif yang mengikutinya. Media sosial tanpa disadari membawa pelanggaran hukum ke dalam dunia siber, salah satunya adalah pelanggaran Hak Kekayaan Intelektual. Menimbang bahwa setiap ciptaan intelektual manusia pada dasarnya harus mendapatkan pengakuan serta pelindungan hukum, maka seluruh tindakan mengeksploitasi penemuan tanpa izin dari Pencipta harus dapat dipertanggungjawabkan. Aktivitas dalam dunia siber bersifat virtual, namun dapat dikategorikan sebagai tindakan hukum (A.M, 2006).

Zaman digital tidak saja berdampak terhadap komunikasi masyarakat semata, melainkan terhadap industri film tanah air. Industri film Indonesia telah menunjukkan peningkatan dalam satu dasawarsa terakhir. Data dari filmindonesia.or.id dan didukung oleh Badan Ekonomi Kreatif (BEKRAF) pada Tahun 2019 menunjukkan bahwa penonton film Indonesia telah mencapai angka 51,2 Juta pada Tahun 2018, serta semakin banyak film Indonesia yang menembus perolehan box office (Levriana Yustriani, Lisabona Rahman 2019). Perkembangan film Indonesia tidak terlepas dari pengaruh Production House. Perusahaan Production House adalah perusahaan jasa pembuatan rekaman audiovisual acara siaran untuk keperluan lembaga penyiaran, sesuai peraturan perundangan yang berlaku (Ayuningtyas 2008).

Film layar lebar merupakan salah satu produk Production House, sehingga keberhasilan atas film mengindikasikan keberhasilan Production House terutama dalam produksi serta pemasaran. Film yang dihasilkan oleh Production House lahir dari karya intelektual seseorang sehingga menghasilkan manfaat ekonomi yang memberikan konsep kekayaan terhadap karya 
intelektual tersebut (Margono, 2010). Menurut Laksono, Production House adalah sebuah badan usaha yang mempunyai organisasi dan keahlian dalam memperoduksi program-program audio dan audiovisual untuk disajikan kepada masyarakat, baik secara langsung maupun melalui broadcasting house (Ayuningtyas, 2008).

Unsur pertama atas pengertian Production House menyatakan bahwa Production House berbentuk badan usaha atau perusahaan. Perusahaan adalah keseluruhan perbuatan secara menerus untuk memperoleh penghasilan dengan cara memperniagakan (Soekardono, 1979). Pasal 1 Ayat (1) Undang-Undang Nomor 8 Tahun 1997 menyatakan perusahaan adalah bentuk usaha yang diselenggarakan perorangan maupun badan usaha, baik badan hukum atau bukan badan hukum (Pasal 1 Angka 1). Badan hukum adalah badan yang memiliki hak dan kewajiban seperti manusia, kekayaan sendiri, serta dapat digugat atau menggugat. Utrecht membagi badan hukum menjadi korporasi dan yayasan. Salah satu bentuk dari korporasi adalah perseroan (Ali 1999).

Mengacu kepada Pasal 1 Ayat (1) Undang-Undang No. 40 Tahun 2007 Tentang Perseroan Terbatas, perseroan merupakan badan hukum. Pengertian perseroan tersebut berkaitan dengan Pasal 1 Ayat (27) Undang-Undang No. 28 Tahun 2014 Tentang Hak Cipta, yang menyatakan bahwa orang atau Pencipta adalah orang perseorangan atau badan hukum. Berdasarkan ketentuan Pasal (2) Butir a Undang-Undang Hak Cipta bahwa Undang-Undang ini berlaku terhadap semua Ciptaan dan produk Hak Terkait warga negara, penduduk, dan badan hukum Indonesia. Berdasarkan penjelasan di atas, Production House sebagai badan hukum Indonesia mendapatkan pelindungan atas karya intelektual, khususnya Hak Cipta dalam Undang-Undang Hak Cipta.

Pasal 1 Ayat (1) Undang-Undang Hak CIpta mendefinisikan Hak Cipta sebagai hak eksklusif yang timbul secara otomatis berdasarkan prinsip deklaratif setelah suatu ciptaan diwujudkan dalam bentuk nyata tanpa mengurangi pembatasan sesuai dengan ketentuan peraturan perundang-undangan. Arti frasa ciptaan pada Pasal 1 Ayat (3) Undang-Undang Hak Cipta adalah setiap karya cipta di bidang ilmu pengetahuan, seni, dan sastra yang diekspresikan dalam bentuk nyata.

Film merupakan salah satu bentuk karya sinematografi mengacu kepada pengertian atas sinematografi. Undang-Undang Hak Cipta mendefiniskan sinematografi sebagai Ciptaan yang berupa gambar bergerak (moving images) antara lain film dokumenter, film iklan, reportase atau film cerita yang dibuat dengan skenario, dan film kartun. Definisi lainnya mengenai 
sinematografi adalah Seni dan teknologi dari fotografi yang bergerak (Alwi, 2010). Mengacu kepada Pasal 40 Undang-Undang Hak Cipta, karya sinematografi merupakan Ciptaan yang dilindungi oleh Undang-Undang Hak Cipta, sehingga segala bentuk kegiatan ekonomi atas film tersebut wajib mendapatkan izin dari Pencipta.

Pelanggaran Hak Cipta dengan jumlah terbesar di Indonesia adalah pembajakan. Pembajakan di bidang Hak Cipta dan Hak Terkait didefinisikan sebagai pembajakan ciptaan baik karya tulis maupun audiovisual dengan menggunakan alat apapun untuk diumumkan dan disiarkan kembali tanpa izin penciptanya (Damian, 2006). Kegiatan pembajakan atas karya sinematografi, khususnya film layar lebar, mampu menurunkan pendapatan film tersebut dari segi penjualan di bioskop. Faktanya salah satu pendapatan terbesar seorang pembuat film adalah penjualan tiket pada bioskop.

Perkembangan teknologi telah memberikan dampak kepada bentuk dari aktivitas pembajakan. Pembajakan telah merambah memasuki dunia digital, seperti melakukan pengunduhan lagu secara illegal, menonton film melalui website yang tidak sah, dan lain sebagainya. Berdasarkan Pasal 9 Ayat (2) Undang-Undang Hak Cipta, pihak yang melakukan kegiatan Hak Ekonomi wajib mendapatkan izin Pencipta atau Pemegang Hak Cipta, termasuk penggandaan Ciptaan serta pendistribusian Ciptaan atau salinannya.

Perkembangan teknologi informasi dan komunikasi telah menjadi salah satu variabel dalam Undang-Undang Hak Cipta. Masuknya perkembangan teknologi disebabkan oleh pro dan kontra yang dimiliki oleh teknologi informasi dan komunikasi. Bidang tersebut memiliki peran dalam pengembangan Hak Cipta, akan tetapi di sisi lain menjadi alat untuk pelanggaran hukum. Kemudahan dalam mengakses dan menggunakan media sosial telah menghasilkan banyak pelaku pelanggaran Hak Cipta. Media sosial adalah saluran berbasis internet untuk memberikan kemudahan bagi pengakses berinteraksi baik secara real time maupun tidak bersamaan (Carr and Hayes, 2015). Media sosial dan perangkat lunak sosial mampu meingkatkan kemampuan sebagai alat untuk berbagi (to share), bekerja sama (to cooperate) antara pengguna dan melakukan tindakan secara kolektif baik diluar kerangka institusional maupun organisasi (Nasrullah, 2017). Kurangnya pengetahuan menyebabkan masyarakat tidak menjadi pengguna media sosial yang cerdas. Tanpa disadari kegiatan yang semula hanya bertujuan untuk mengunggah keseharian menjadi pelanggaran atas Hak Cipta.

Pada penelitian ini, Penulis mengerucutkan pada pelanggaran Hak Cipta terhadap film yang sedang tayang di bioskop melalui media sosial. Perusahaan Media Nusantara Citra 
Productions Entertainment selanjutnya disebut MNC Pictures, adalah rumah produksi sinetron dan film yang merupakan bagian dari MNC Studios International. Satu dari sekian film yang diproduksi oleh MNC Pictures adalah film berjudul Me Vs. Mami yang diperankan oleh Irish Bella dan Cut Mini Theo yang ditayangkan di bioskop pada Tahun 2016.

Berdasarkan berita yang dilansir berita nasional Antara News, seorang mahasiswi membagi aktivitasnya kepada para pengikut media sosial mendapatkan perhatian lebih dari MNC Pictures. Bertujuan hanya untuk meningkatkan popularitas, Merlina Ardiyah melakukan live video streaming pada saat menyaksikan film Me vs Mami di bioskop melalui media sosial Bigo Live dengan durasi 17 Menit. Rumah produksi MNC selaku pemegang Hak Cipta dari film Me Vs Mami melaporkan aksi tersebut kepada pihak berwenang atas pelanggaran UndangUndang Hak Cipta.

Tindakan yang dilakukan oleh Merlina Ardiyah, yaitu melakukan live video streaming pada media sosial Bigo Live merupakan bentuk dari pelanggaran atas Ciptaan seseorang, dalam kasus ini Ciptaan MNC Pictures. Tindakan tersebut dapat menyebabkan kerugian secara materil maupun immaterial yang dialami oleh berbagai pihak terutama bagi pihak Production House. Modal dalam jumlah besar yang dikeluarkan oleh rumah produksi mulai dari proses development, pre-production, production, post-production, distribution and advertising, dan exhibition (Manurung, 2016) tersebut dapat merugi atas tindakan pelanggaran Hak Ekonomi dari Ciptaannya. Sebagaimana disebutkan sebelumnya pada Pasal 9 Undang-Undang Hak Cipta segala bentuk kegiatan Hak Ekonomi wajib mendapatkan persetujuan MNC Pictures.

Aplikasi media sosial Bigo Live merupakan situs jejaring sosial media yang berbasis streaming video online. Pengguna bigo dapat melakukan interaksi dengan cara memberikan komentar, like, atau gift kepada video yang ditayangkan oleh penyiar (broadcaster). Aplikasi Bigo Live dapat menjadi ladang uang bagi mereka yang mampu membuat video yang kreatif dan menarik viewers. Pendapatan pada Bigo Live dihasilkan broadcaster melalui perolehan gift yang berupa diamonds dan beans. Berdasarkan berita yang dilansir oleh TribunJogja pada tahun 2016, pengguna Bigo dapat menukarkan diamonds menjadi uang dengan ketentuan minimal mencapai 60 buah. Jumlah tersebut dapat ditukarkan dalam bentuk mata uang lain seperti USD. Kepemilikan 10 diamonds setara dengan 3 beans, sehingga 60 diamonds setara dengan 200 beans.

Arti frasa pembajakan menurut Kamus Besar Bahasa Indonesia memiliki arti penyalinan, pendistribusian, atau penggunaan perangkat lunak secara tidak sah. Merekam 
tayangan dalam bioskop merupakan aksi dari "penyalinan" dan melakukan live streaming melalui media sosial merupakan aksi dari "pendistribusian" kembali. Berdasarkan penjelasan tersebut unsur dari pelanggaran atas Hak Ekonomi Pencipta yang tertuang dalam Pasal 9 Ayat (1) Undang-Undang Hak Cipta dalam bentuk live video streaming telah terpenuhi begitu juga dengan unsur dari kegiatan pembajakan, yang sebagaimana tertera pada Pasal 9 Ayat (1) itu sendiri yang menyatakan, penggandaan dalam bentuk apapun.

Mengacu kepada Pasal 96 Undang-Undang Hak Cipta rumah produksi MNC berhak untuk mengajukan gugatan ganti rugi atas pelanggaran tersebut sebagai bentuk akibat hukum dari tindakan hukum. Mengacu kepada Pasal 113 Undang-Undang Hak Cipta berdasarkan ketentuan pidana, dinyatakan bahwa setiap orang dengan tanpa hak yang melakukan pelanggaran Hak Ekonomi Pencipta dapat dipidana dengan pidana penjara dan/atau pidana denda.

Berdasarkan latar belakang atas masalah yang telah dijelaskan di atas, penelitian ini bertujuan untuk memberikan perlindungan hukum bagi rumah produksi sebagai pemegang Hak Cipta serta memberikan pengetahuan mengenai tindakan hukum yang dapat dilakukan oleh production house terhadap kerugian ekonomi yang ditimbulkan atas tindakan penyiaran film bioskop tanpa izin melalui media sosial. Penelitian ini diharapkan dapat meningkatkan kesadaran masyarakat bahwa sebagai pengguna teknologi informasi lebih cerdas dalam menggunakan media sosial serta menyadari bahwa penyiaran kembali film yang sedang tayang di bioskop melalui media sosial merupakan tindakan yang tergolong ke dalam pembajakan. Penelitian ini diharapkan dapat menjadi sumber belajar masyarakat bahwa pelanggaran hak cipta merupakan hal yang serius dan tidak dapat dipandang sebelah mata. Harapan dari penelitian ini dapat mendorong pihak Production House agar tidak mengabaikan tindakan pelanggaran Hak Cipta guna mengurangi jumlah pelanggaran.

\section{METODE PENELITIAN}

Penelitian menggunakan metode analisis data yaitu analisis yuridis kualitatif. Teknik analisis yuridis kualitatif adalah cara menganalisis permasalahan serta menarik kesimpulan berdasarkan norma, kaidah, asas dan peraturan perundang-undangan yang relevan dengan topik permasalahan (Sugiyono, 2016). Penelitian yang sedang dilakukan oleh penulis menggunakan metode pendekatan yuridis normatif, yaitu penelitian hukum yang dilakukan dengan cara meneliti bahan pustaka atau data sekunder sebagai bahan dasar untuk diteliti dengan cara 
mengadakan penelusuran terhadap peraturan-peraturan dan literatur-literatur yang berkaitan dengan permasalahan yang diteliti (Soekanto and Mamudji, 2013).

Teknik pengumpulan data yang penulis gunakan dalam penelitian ini adalah studi pustaka. Studi pustaka atau library research merupakan serangkaian kegiatan yang berkenaan dengan metode pengumpulan data pustaka, membaca dan mencatat serta mengolah bahan penelitian (Supriyadi, 2016). Sehingga penulis melakukan penelitian terhadap literatur serta dokumen yang erat kaitannya dengan perlindungan terhadap rumah produksi atas penyiaran film yang sedang tayang di bioskop tanpa izin melalui media sosial Bigo Live. Metode yang digunakan adalah penelitian literatur yaitu penelitian secara normatif. Hal ini mengacu kepada norma hukum yang terkandung dalam Undang-Undang dan praktik yang berlaku di masyarakat saat ini (Soekanto and Mamudji, 1979). Seperti halnya penelitian normatif, materi penelitian hukum dilakukan berdasarkan meninjau berbagai literatur untuk menilai masalahnya (Soekanto and Mamudji, 1979),khususnya Undang-Undang No. 28 Tahun 2014 Tentang Hak Cipta (Isnaini, 2009).

\section{HASIL DAN PEMBAHASAN}

Perusahaan rumah produksi atau Production House merupakan jenis usaha yang menyediakan layanan jasa produksi film. Sebagai suatu perusahaan, Production House memiliki tujuan yakni mencari profit sebesar-besarnya, terlebih dengan biaya mahal yang telah dikeluarkan oleh perusahaan produksi. Modal besar yang dikeluarkan dalam pembuatan sebuah film diharapkan dapat menghasilkan film yang menarik bagi masyarakat yang mana merupakan pendapatan bagi perusahaan itu sendiri. Daya cipta perusahaan rumah produksi adalah aspek yang dibutuhkan untuk mendapatkan keuntungan. Segala bentuk aktivitas yang melanggar hak perusahaan mampu mengurangi jumlah pendapatan suatu karya film sehingga menimbulkan kerugian bagi Production House.

Production House merupakan perusahaan yang menghasilkan karya sinematografi, dimana produk yang dihasilkan oleh rumah produksi merupakan Ciptaan yang dilindungi oleh Undang-Undang No. 28 Tahun 2014 Tentang Hak Cipta pada Pasal 40 Ayat (1). Film Me Vs Mami adalah salah satu karya sinematografi yang dihasilkan oleh MNC Pictures dalam kategori film cerita atau fiksi yang dikarang dan dimainkan oleh aktor/aktris (Sumarno, 1996). Sebagai sebuah karya cipta yang dilindungi, pemegang Hak Cipta atas film tersebut pun dilindungi oleh hukum. 
Pasal 1 Angka (27) Undang-Undang No. 28 Tahun 2014 Tentang Hak Cipta menyatakan bahwa orang atau Pencipta adalah orang perseorangan atau badan hukum. Dijelaskan kembali pada Pasal 2 Butir (a) Undang-Undang Hak Cipta bahwa Undang-Undang ini berlaku terhadap semua Ciptaan dan produk Hak Terkait warga negara, penduduk, dan badan hukum Indonesia. Telah dijelaskan sebelumnya bahwa MNC Pictures merupakan badan hukum berbentuk Perseroan Terbatas (PT), maka MNC Pictures merupakan sebuah subjek hukum yang dilindungi oleh Undang-Undang Hak Cipta.

Film Me Vs Mami merupakan film yang diangkat dari sinetron RCTI (milik MNC Group) oleh MNC Pictures itu sendiri. Pembuatan film tersebut menggunakan karyawan inhouse dari MNC Pictures sendiri yaitu para produser, serta memperkerjakan freelancer hanya sampai proyek film ini selesai seperti sutradara, penulis, editor, dan crew lainnya (Ferina, 2020).

Pasal 34 Undang-Undang Hak Cipta menyatakan bahwa dalam hal Ciptaan dirancang oleh seseorang dan diwujudkan serta dikerjakan oleh Orang lain di bawah pimpinan dan pengawasan Orang yang merancang, yang dianggap Pencipta yaitu Orang yang merancang Ciptaan. Diperjelas kembali melalui Pasal 37 yang menyatakan bahwa kecuali terbukti sebaliknya, dalam hal badan hukum melakukan Pengumuman, Pendistribusian, atau Komunikasi atas Ciptaan yang berasal dari badan hukum tersebut, dengan tanpa menyebut seseorang sebagai Pencipta, yang dianggap sebagai Pencipta yaitu badan hukum. Mengacu kepada ketentuan pada Pasal 37 tersebut dapat diketahui bahwa MNC Pictures merupakan pihak yang dianggap sebagai Pencipta atas karya sinematografi film Me Vs Mami dalam bentuk badan hukum. Pengumuman, pendistribusian, atau komunikasi atas Ciptaan berasal dari badan hukum MNC Production Entertainment (bagian dari MNC Studios International).

Rumah produksi MNC Pictures sebagai pemegang Hak Cipta film Me Vs Mami memiliki Hak Moral dan Hak ekonomi. Hak Moral sebagaimana tercantum pada Pasal 4 Undang-Undang Hak Cipta. Kemudian Hak Ekonomi sesuai ketentuan Pasal 8 Undang-Undang Hak Cipta merupakan hak eksklusif Pencipta atau Pemegang Hak Cipta untuk mendapatkan manfaat ekonomi atas Ciptaan. Mengacu kepada Pasal 9 Ayat (1) MNC Pictures sebagai Pencipta sebagaimana dimaksud dalam Pasal 8 memiliki Hak Ekonomi untuk melakukan penerbitan Ciptaan, penggandaan Ciptaan dalam segala bentuk, penerjemahan Ciptaan, pengadaptasian atau pentransformasian Ciptaan, pendistribusian Ciptaan atau salinannya, pertunjukan Ciptaan, pengumuman CIptaan, komunikasi Ciptaan, dan penyewaan Ciptaan. Secara umum MNC Pictures dapat melakukan Hak Ekonomi, anatara lain: (Isnaini, 2009) 
1. Hak reproduksi atau penggandaan, yaitu penambahan jumlah Ciptaan baik secara permanen maupun temporer. MNC Pictures memiliki Hak Ekonomi untuk melakukan perubahan bentuk Ciptaan, dalam hal ini yaitu bermula dari sinetron menjadi film layar lebar, perubahan rekaman musik, duplikasi atas film, dan sebagainya.

2. Hak adaptasi, yaitu penerjemahan dari suatu bahasa ke bahasa lain, melakukan aransemen musik, melakukan dramatisasi, mengubah jalan cerita agar sesuai dengan screenplay untuk film layar lebar Me Vs Mami.

3. Hak distribusi dan hak penyiaran, yaitu hak yang dimiliki oleh Pencipta untuk menyebarkan kepada masyarakat setiap hasil Ciptaannya. Rumah produksi MNC Pictures memiliki Hak Ekonomi untuk melakukan pendistribusian dalam bentuk penayangan di bioskop, mengiklankan melalui radio, dan penjualan DVD agar dikenal oleh masyarakat.

4. Hak program kabel, yaitu melakukan penyiaran melalui transmisi kabel kepada stasiun televisi. Perusahaan MNC Pictures memiliki Hak Ekonomi untuk menayangkan film Me Vs Mami pada program televisi baik milik MNC Group maupun tidak.

Hak Ekonomi yang telah dipaparkan di atas merupakan hak yang sah secara hukum dimiliki oleh MNC Pictures selaku Pencipta untuk mengeksploitasi karyanya demi mendapatkan keuntungan ekonomi atas Ciptaannya. Ketentuan pada Pasal 9 Ayat (2) menyatakan bahwa setiap Orang yang melaksanakan Hak Ekonomi sebagaimana dimaksud pada ayat (1) wajib mendapatkan izin Pencipta atau Pemegang Hak Cipta. Mengacu kepada ketentuan Undang-Undang Hak Cipta, maka siapapun yang hendak melaksanakan Hak Ekonomi harus mendapatkan izin dari MNC Pictures selaku pemegang Hak Cipta.

Rista Ferina, selaku produser dalam film Me Vs Mami menyatakan bahwa seluruh biaya produksi dikeluarkan oleh MNC Pictures selaku pemegang Hak Cipta. Karyawan yang bekerja dibawah MNC Pictures, baik in-house maupun freelancer mendapatkan Hak Ekonomi dengan cara pemberian gaji dan honorarium dari MNC Pictures, sementara Hak Moral yang dimiliki oleh karyawan adalah dengan dicantumkan nama pada credits film, cover, dan media komunikasi lainnya (Ferina, 2020).

Merlina Ardiah merupakan seorang mahasiswi berdomisili di Jalan Dr Soetomo, Kelurahan Sidodadi, Samarinda. Merlina merupakan mahasiswi angkatan 2011 Fakultas Ekonomi dan Bisnis Universitas Mulawarman, Samarinda. Merlina telah melakukan penggandaan serta pendistribusian kembali seperti yang tercantum pada Pasal 9 Ayat (1) tanpa 
izin dari MNC Pictures. Tindakan tersebut dilakukan melalui live video streaming Bigo Live akun pribadinya. Pasal 1 Ayat (12) Undang-Undang Hak Cipta menyatakan bahwa arti frasa penggandaan adalah proses, perbuatan, atau cara menggandakan satu salinan Ciptaan dan/atau fonogram atau lebih dengan cara dan dalam bentuk apapun, secara permanen atau sementara. Aktivitas yang dilakukan oleh Merlina melalui aplikasi Bigo Live adalah mengunggah konten secara langsung atau live kepada masyarakat baik pengikut akunnya maupun tidak. Proses pengunggahan video secara live streaming tersebut melalui proses perekaman film yang sedang tayang dengan ponsel atau telepon genggamnya dengan durasi 17 Menit. Merekam film merupakan tindakan menggandakan suatu Ciptaan, dimana semula hanya terdapat pada layar bioskop menjadi terdapat pada telepon genggam milik Merlina melalui media sosial Bigo Live.

Pasal 1 Ayat (17) Undang-Undang Hak Cipta menjelaskan pendistribusian sebagai penjualan, pengedaran, dan/atau penyebaran Ciptaan dan/atau produk Hak Terkait. Merlina merekam film Me Vs Mami ketika sedang tayang di bioskop melalui aplikasi Bigo Live kemudian disiarkan atau streaming yaitu menyiarkan hasil rekaman ke platform live streaming melalui internet. Aktivitas tersebut merupakan tindakan pendistribusian atas film Me Vs Mami melalui Bigo Live tanpa izin dari MNC Pictures. Aktivitas penggandaan serta pendistribusian kembali tergolong ke dalam kategori pembajakan sesuai ketentuan pada Pasal 1 Angka (23). Sehingga penggandaan serta pendistribusian kembali yang dilakukan oleh Merlina melalui media sosialnya telah memenuhi unsur dari pelanggaran Hak Cipta pembajakan terhadap karya sinematografi film Me Vs Mami hasil produksi MNC Pictures yang sedang tayang di bioskop.

Perusahaan MNC Pictures merupakan badan hukum yang mendapatkan perlindungan atas karya Ciptaannya. Berdasarkan ketentuan yang telah dipaparkan di atas, diketahui bahwa rumah produksi MNC Pictures adalah pemegang Hak Cipta atas film Me Vs Mami. Sebagai pemegang Hak Cipta dan Ciptaan yang dilindungi maka ketentuan pada Undang-Undang Nomor 28 Tahun 2014 Tentang Hak Cipta berlaku terhadap MNC Pictures serta Film Me Vs Mami tanpa pengecualian. Pelindungan hukum atas tindakan pelanggaran Hak Cipta pembajakan yang melanggar Hak Ekonomi serta Hak Moral Pencipta, yang mana mampu merugikan Pencipta dalam bentuk apapun, termasuk di dalamnya melalui akun media sosial Bigo Live.

Tuntutan ganti rugi secara perdata terbagi menjadi dua jenis, yaitu tuntutan ganti rugi berdasarkan perbuatan melawan hukum dan tuntutan ganti rugi berdasarkan Wanprestasi (Djojodirdjo, 1979). Tuntutan ganti rugi merupakan salah satu tindakan hukum yang dapat 
dilakukan oleh rumah produksi terhadap kerugian ekonomi yang dirasakan, serta bentuk tanggungjawab yang dapat dituntut kepada pihak yang melakukan pelanggaran atas Hak Cipta. Sebagaimana dinyatakan pada Pasal 1365 KUHPerdata, yakni perbuatan melawan hukum, yang membawa kerugian bagi orang lain, mewajibkan orang yang karena salahnya menerbitkan kerugian itu, mengganti kerugian tersebut. Berdasarkan pasal tersebut dapat ditarik empat unsur, antara lain terdapat perbuatan melawan hukum, terdapat kesalahan, terdapat hubungan sebab akibat antara kerugian dan perbuatan, dan terdapat kerugian.

Pembajakan film yang sedang tayang di bioskop melalui live video streaming Bigo Live merupakan bentuk perbuatan melawan hukum. Tindakan Merlina melanggar ketentuan Undang-Undang Nomor 28 Tahun 2014 Tentang Hak Cipta serta hak subjektif Pencipta. MNC Pictures sebagai Pencipta memiliki Hak Ekonomi dan Hak Moral yang dijamin oleh hukum dan harus dihargai. Penyiaran kembali film yang sedang tayang di bioskop melalui live video streaming Bigo Live telah terbukti melanggar Hak Moral dalam ketentuan Pasal 5 UndangUndang Hak Cipta, serta Hak Ekonomi Pencipta pada Pasal 9 Undang-Undang Hak Cipta.

Unsur kesalahan dalam tindakan pembajakan yang dilakukan oleh Merlina terpenuhi. Merlina secara sadar melakukan perbuatanya dan mengetahui konsekuensi atas perbuatannya. Bioskop selalu memberikan peringatan berupa larangan merekam film yang sedang tayang, anjuran bagi penonton untuk melaporkan apabila melihat aktivitas tersebut, serta tercantum bahwa tindakan penyiaran kembali dapat melanggar Undang-Undang Hak Cipta. Tujuan peringatan sebelum film dimulai adalah untuk mengurangi jumlah pelanggaran Hak Cipta atas film. Perbuatan penggandaan serta pendistribusian kembali film yang sedang tayang di bioskop dapat menimbulkan kerugian terhadap Pencipta atau pemegang Hak Cipta. Menyiarkan film yang sedang tayang di bioskop dapat mengurangi jumlah pendapatan suatu film melalui penurunan pembelian tiket, sebab masyarakat cenderung memilih menyaksikan melalui internet dengan gratis.

Unsur sebab akibat pada kasus Merlina yang melakukan penyiaran kembali melalui live video streaming Bigo Live terpenuhi. Media sosial memiliki andil yang besar pada era ini. Masyarakat dikatakan sebagai masyarakat digital, sehingga review atau pendapat individu pada media sosial sangat berpengaruh terhadap rating dan jumlah penonton suatu film. Perusahaan rumah produksi telah membuat cuplikan singkat atau trailer dengan berisikan adegan menarik yang mampu menimbulkan rasa penasaran pada penonton. Adegan tidak menarik dan spoiler yang terkandung pada akun Bigo Live Merlina dapat menimbulkan penurunan penjualan tiket 
bioskop yang merupakan pendapat utama atas pembuatan film, sehingga terdapat hubungan sebab akibat antara tindakan dengan kerugian yang ditimbulkan (Ferina, 2020).

Unsur adanya kerugian pada aktivitas pembajakan terpenuhi dalam kasus Merlina. Akibat perbuatannya dapat menimbulkan kerugian, baik kerugian secara materil maupun kerugian secara imateril. Penjelasan sebelumnya telah menyebutkan dampak kerugian secara materil yaitu penurunan jumlah penonton di bioskop sehingga pendapatan berkurang. Pembuatan film membutuhkan biaya yang besar sehingga diharapkan dapat mendapat keuntungan. Kerugian imateril dirasakan dengan pelanggaran Hak Moral dalam bentuk infringement of copyrights, yakni penggunaan secara tidak sah atas materi yang berada di bawah perlindungan Hak Cipta (Black, 1990) dengan cara duplikasi langsung melalui video perekam pada bagian film atau secara menyeluruh, dalam kasus ini live video dilakukan selama 17 menit.

Pembajakan merupakan penggandaan Ciptaan dan/atau produk Hak Terkait secara tidak sah dan pendistribusian barang hasil penggandaan dimaksud secara luas untuk memperoleh keuntungan ekonomi (Pasal 1 Ayat (23) Undang-Undang Hak Cipta). Pembajakan dilakukan melalui live video streaming Bigo Live yang sudah merupakan lifestyle bagi Merlina. Berbeda dengan pembajakan kaset yang mendapatkan keuntungan atas penjualan DVD, Bigo Live dapat memberikan keuntungan melalui perolehan token apresiasi atau gift berupa diamonds atau beans yang dapat ditukarkan ke dalam bentuk mata uang baik USD maupun Rupiah. Konten yang diunggah oleh Merlina tidak bertujuan untuk menjual film Me Vs Mami secara langsung, namun unsur memperoleh keuntungan ekonomi terpenuhi dalam durasi 17 menit video streaming Bigo Live karena publikasi film merupakan konten menarik untuk mendapatkan lebih banyak viewers dan followers demi kebutuhan peningkatan publikasi yang sejalan dengan peningkatan gift atau penghasilan. Tindakan Merlina telah memberikan dampak penurunan pendapatan tiket bioskop serta moralitas crew MNC Pictures atas penggunaan film tanpa izin sebagai konten peningkatan publikasi dan popularitas.

Berdasarkan Undang-Undang Hak Cipta, ganti rugi adalah pembayaran sejumlah uang yang dibebankan kepada pelaku pelanggaran hak ekonomi Pencipta, Pemegang Hak Cipta dan/atau pemilik Hak Terkait berdasarkan putusan pengadilan perkara perdata atau pidana yang berkekuatan hukum tetap atas kerugian yang diderita Pencipta, Pemegang Hak Cipta dan/atau pemilik Hak Terkait. Mengenai gugatan ganti rugi telah disebutkan dalam Pasal 96 UndangUndang Hak CIpta, yang berisi Pencipta, pemegang Hak Cipta dan/atau pemegang Hak Terkait atau ahli warisnya yang mengalami kerugian Hak Ekonomi berhak memperoleh Ganti Rugi. 
Mengacu kepada Pasal 95 Undang-Undang Hak Cipta, dapat diketahui bahwa Production House dapat melakukan penyelesaian sengketa melalui alternatif penyelesaian sengketa, arbitrase, atau pengadilan. Perusahaan rumah produksi dapat melakukan penyelesaian sengketa melalui pengadilan yang berwenang yakni Pengadilan Niaga. Secara umum setiap penyelesaian sengketa Hak Cipta wajib menempuh penyelesaian sengketa melalui mediasi, namun dalam kasus pembajakan seperti yang dilakukan oleh Merlina terhadap film Me Vs Mami, Production House tidak memiliki kewajiban untuk menyelesaikan sengketa melalui mediasi sebelum melakukan tuntutan pidana.

Ketentuan Pasal 95 Ayat (4) mengenai mediasi bersinggungan dengan ketentuan yang tercantum pada Pasal 105 Undang-Undang Hak CIpta yang bebunyi Hak untuk mengajukan gugatan keperdataan atas pelanggaran Hak Cipta dan/atau Hak Terkait tidak mengurangi Hak Pencipta dan/atau pemilik Hak Terkait untuk menuntut secara pidana. Perusahaan rumah produksi diwajibkan untuk melakukan penyelesaian sengketa mediasi atas tindakan pelanggaran Hak Cipta, kecuali pada kasus pembajakan. Kewajiban yang tercantum pada Pasal 95 Ayat (4) tersebut tidak mengurangi hak Production House untuk melakukan tuntutan secara pidana. Pada tuntutan secara pidana ganti kerugian diberikan dan dicantumkan sekaligus dalam amar putusan pengadilan tentang perkara tindak pidana Hak Cipta dan/atau Hak Terkait. Pembayaran ganti rugi yang akan diberikan oleh Pelaku akan dibayarkan paling lama 6 (enam) bulan setelah putusan pengadilan yang berkekuatan hukum tetap kepada perusahaan Production House.

Bentuk tanggung jawab pelaku secara pidana telah diatur oleh Undang-Undang Nomor 28 Tahun 2014 Tentang Hak Cipta pada Pasal 113. Dalam ranah pidana perusahaan rumah produksi atau Production House dapat melayangkan tuntutan pidana berdasarkan Pasal 113 Ayat (3) yang mengatur mengenai pelanggaran hak ekonomi Pencipta atau Pemegang Hak Cipta atas tindakan penggandaan dalam bentuk apapun serta pendistribusian Salinan Hak Cipta yang tergolong aktivitas pembajakan sebagaimana dilakukan oleh Merlina melalui live video streaming Bigo Live. Bentuk pertanggungjawaban yang dapat dilakukan berdasarkan ketentuan Pasal 113 Ayat (3) Undang-Undang Hak Cipta dengan pidana penjara paling lama 4 (empat) tahun dan/atau pidana denda paling banyak Rp1.000.000.000,00 (satu miliar rupiah). 


\section{KESIMPULAN}

Perusahaan MNC Pictures merupakan salah satu production house di Indonesia, sebagai badan hukum berbentuk Perseroan Terbatas (PT), MNC Pictures mendapatkan perlindungan hukum atas karya ciptanya sesuai dalam ketentuan Pasal 2(a) Undang-Undang Nomor 28 Tahun 2014 Tentang Hak Cipta. MNC Pictures merupakan perusahaan yang bergerak dalam pembuatan karya sinematografi, ciptaan yang dilindungi mengacu kepada Pasal 40 Ayat (1) butir M Undang-Undang Hak Cipta. Karya sinematografi Me Vs Mami merupakan karya MNC Pictures dengan menggunakan karyawan in-house MNC serta karyawan freelancer per-proyek atas biaya sepenuhnya dari MNC Pictures. Bab IV Undang-Undang Hak Cipta telah mengatur mengenai Pencipta, pada Pasal 34 dan Pasal 37 menyatakan bahwa apabila ciptaan dikerjakan oleh orang lain di bawah pengawasan orang yang merancang yang dianggap Pencipta yaitu orang yang merancang serta MNC Pictures selaku badan hukum melakukan pengumuman dan pendistribusian atas film Me Vs Mami merupakan pemegang hak cipta serta badan hukum yang dilindungi oleh Undang-Undang Hak CIpta. MNC Pictures mengeluarkan biaya yang besar dalam pembuatan karya sinematografi, maka MNC Pictures berhak untuk mengajukan gugatan atas segala tindakan yang mampu merugikan Production House serta melanggar Hak Ekonomi dan Hak Moral Pencipta. MNC Pictures berhak untuk menuntut ganti kerugian secara perdata yang didasarkan dengan perbuatan melawan hukum kepada pihak yang bersangkutan atas kerugian ekonomi yang timbul dari tindakan tersebut berdasarkan ketentuan Bab XIV mengenai Penyelesaian Sengketa Pasal 95, Pasal 96 Undang-Undang Hak Cipta. Undang-Undang Hak Cipta tidak mengurangi hak MNC PIctures untuk menuntut secara pidana sesuai dengan ketentuan Pasal 105. Bentuk pertanggungjawaban yang dapat dilakukan berdasarkan ketentuan Pasal 113 Ayat (3) Undang-Undang Hak Cipta dengan pidana penjara dan/atau pidana denda.

\section{REFERENSI}

A.M, Ramli. (2006). Cyber Law Dan HAKI. Jakarta: Aditama.

Ali, Chidir. (1999). Badan Hukum. Bandung: Alumni.

Alwi, Sofyan. (2010). Sinematografi. Bandung: Gramedia

Ayuningtyas, Rr Nurina. (2008). Penentuan Pajak Pertambahan Nilai Terutang Atas Penyerahan Paket Program Acara Ke Stasiun Televisi Oleh Rumah Produksi. Depok: Universitas Indonesia. 
Black, H.C. (1990). Black's Law Dictionary. St Paul Minn: West Group.

Carr, Caleb T, and Rebecca A Hayes. (2015). "Social Media: Defining, Developing, and Divining." Atlantic Journal of Communication 23(1): 46-65. https://doi.org/10.1080/15456870.2015.972282.

Damian, Eddy. (2006). Plagiat Dan Pembajakan Sebagai Pelanggaran Hukum Hak Cipta. Indonesian Journal of International Law 3(2): 195-211.

Djojodirdjo, M.A Moegni. (1979). Perbuatan Melawan Hukum. Jakarta: Pradnya Paramitha.

Ferina, R. (2020). Pelindungan Hukum Bagi Rumah Produksi Terhadap Tindakan Penyiaran Film Yang Sedang Tayang Di Bioskop Oleh Pihak Lain Tanpa Izin Melalui Live Video Streaming Bigo Live Berdasarkan Undang-Undang No. 28 Tahun 2014 Tentang Hak Cipta.

Isnaini, Yusran. (2009). Hak Cipta Dan Tantangannya Di Era Cyber Space. Bogor: Ghalia Indonesia.

Yustriani, Levriana and Rahman, Lisabona. (2019). Analisis Data Kajian Pemandangan Umum Industri Film 2019. Jakarta: Badan Ekonomi Kreatif Republik Indonesia. https://www.bekraf.go.id/pustaka/page/pemandangan-umum-industri-film-indonesia2019

Manurung, Elvy Maria. (2016). Paradoks Dan Manajemen Kreativitas Dalam Industri Film Indonesia. Satya Wacana University Press: 67-153.

Margono, Suyud. (2010). Aspek Hukum Komersialisasi Aset Intelektual. Bandung: Nuansa Aulia.

Nasrullah, Rulli. (2017). Media Sosial: Perspektif Komunikasi, Budaya, Dan Sosioteknolog. Bandung: Remaja Rosdakarya.

Nasution, R. (2017). Effect of the Development of Communication Information Technology on Local Cultural Existence - Pengaruh Perkembangan Teknologi Informasi Komunikasi Terhadap Eksistensi Budaya Lokal. Jurnal Penelitian Komunikasi dan Opini Publik 21(1): 123858.

Soekanto, Soerjono, and Sri Mamudji. (1979). Peranan Dan Penggunaan Kepustakaan Di Dalam Penelitian Hukum. Jakarta: Pusat Dokumentasi Universitas Indonesia.

_. (2013). Penelitian Hukum Normatif. Jakarta: PT. Raja Grafindo Persada.

Soekardono, Raden. (1979). Hukum Dagan Indonesia. Jakarta: Dian Rakyat.

Sugiyono. (2016). Metode Penelitian Kualitatif. Bandung: CV Alfabeta.

Sumarno, Marselli. (1996). Dasar-Dasar Apresiasi Film. Jakarta: Gramedia.

Supriyadi, Supriyadi. (2016). Community of Practitioners: Solusi Alternatif Berbagi Pengetahuan Antar Pustakawan. Lentera Pustaka: Jurnal Kajian Ilmu Perpustakaan, Informasi dan Kearsipan; Vol 2, No 2 (2016): Desember 2016DO 10.14710/lenpust.v2i2.13476

https://ejournal.undip.ac.id/index.php/lpustaka/article/view/13476. 